\title{
Effect of Dry Season Tomato Farming on Poverty Alleviation among Women Farmers in Niger State, Nigeria
}

Olaleye, R. S, Umar, I. S. and Ndanitsa, M. A.

Dept. of Agric. Econs. and Ext. Tech

Federal University of Technology

Minna, Niger State, Nigeria

E-mail address: olaleyerotimidavid@yahoo.com

\begin{abstract}
Generally, the study examines the effect of dry season tomato farming on poverty alleviation among women farmers in Niger State, Nigeria. Specifically, it examines the demographic and socio-economic characteristics of the women dry season tomato farmers, their major sources of resources for tomato farming, marketing and marketing channels for tomato produced as well as the monthly income generated from the sales of harvested tomatoes and the effect on poverty alleviation in terms of provision for food, clothing, housing, health care and children's education. Three Local Government Areas (LGAs), from each of the three geo-political zones of the State were purposively selected .A total of 15 villages were randomly selected from these LGAs and based on the preponderance of women tomato farmers, respondents were purposively selected to give a total of 233 . Findings showed that over one-half of the respondents (52.4\%), had formal education and married (53.2\%), with majority $(91.3 \%)$, of them having four and more people in their households.Morever,41.6\% of the women practiced farming as their major occupation. Furthermore, over two-thirds of them cultivated 0.5 ha of tomato farm, while only $2.1 \%$ of them cultivated above 1 ha. Findings indicated that majority of them had more than four years tomato farming experience and access to farm land was never a problem but many of them (51.9\%), relied mostly on family labour. Niger State Agricultural Development (NSADP) plays a leading role in the provision of relevant technical information to most of the women farmers especially, in the areas of improved seed varieties among others. Results showed that many of the women (61.7\%), usually sold their produce at the village markets ,mostly every week either in retails or in bulks or both(47.6\%) with an estimated monthly income of between N6,000 and N15,000 by many of them (63\%).In view of this, their expenditure performances indicated that many of the women farmers were above average in meeting the following basic needs; food (52\%), clothing (48.1\%), housing (57\%), health care (39.9\%) and children's education (19.4\%). Generally the effect of dry season tomato farming on poverty reduction as indicated by majority of the women farmers was on the high side. Chi-square tests showed significant relationships between some independent variables and the effect of dry season tomato farming as strategy for poverty reduction; household size $\left(\left(X^{2}=246.29, P<0.05\right)\right.$, children's education $\left(X^{2}=353.3, P<0.05\right)$ and tomato farming experience $\left(X^{2}=121.7, P<0.05\right)$ as well as correlation between income generated and the effect of dry season tomato
\end{abstract}


Journal of Agricultural Extension

Vol. 13 (2) December 2009

\begin{abstract}
farming ( $r=0.85, \quad P<0.05)$. Cobb-Douglas multiple regression analysis model showed a significant relationship between contributions to household expenditures and the effect of dry season tomato farming $(F=6.54, P<0.05)$. Housing ( $t=-3.85, P<0.05)$, clothing $(t=-3.56, P<0.05)$ and food $(t=-2.31, P<0.05)$ were inverse but significant in explaining $62 \%$ variation in the effect of dry season tomato farming on poverty reduction. This implies that the more the income realized to meet these basic needs the less the effect of poverty and vice versa. Analysis of Variance also showed a significant difference between household size, income generated and the effect of dry season tomato farming on poverty alleviation ( $F=172.5, P<0.05)$. Conclusively, income generated from dry season tomato farming, to certain extent helped in poverty reduction among women farmers. It is recommended that improved credit assistance and labour saving devices should be put in place to further empower women economically, while special attention is being paid to health care and children's education.
\end{abstract}

\title{
INTRODUCTION
}

Poverty alleviation describes strategies to eradicate poverty. It is any process which seeks to reduce the level of poverty in a community or among a group of people. Most approaches to poverty alleviation focus on income and subsidy measures. Globally, it was estimated that 1.3 billion people had incomes below the poverty line in 1993 and this had risen to more than 1.4 billion people in the year 2000. (World Bank, 1996). Poverty had various dimensions but that of food is the most fundamental since food accounts for 80 percent of all human basic needs. People who are chronically lacking access to sufficient food are considered to be poor. The number of poor is defined in terms of those people with an income level which does not allow them to access sufficient food. It is also closely associated with a person's least of access to production assets, services and markets. Without access to these, it is unlikely that production and income earning capabilities can be improved on sustainable basis. Therefore, low income limits the poor the ability to produce and or purchase food and other domestically produced products and services (United Nations, 1997). The problems of farmers' income and poverty stem from major factor, such as shortage of water for agriculture, inconsistent rainfall distribution and depletion of farm land. Rain fed agricultural land amounts to 81 percent of the total cultivation in the world, though Nigeria has history of irrigation or fadama farming activities.

The most important part of the population that needs to be involved in poverty alleviation is the women in Africa, especially Nigerian women. This is largely because they have become the main producers of local food. This is not to say that they are totally excluded from the production of commercial crops, but that women are more responsible for the feeding of most families and children. They have also become the main labour force in the rural areas due to the absence of men who are seeking works in urban areas (European Commission, 1996).

In a study conducted by Kelly et al. (2003) it was found out that among a number of significant poverty impacts, the strongest was the case of vegetables farming technologies which was targeted towards households with relatively small amounts of land and very low investments. It also revealed a substantial returns and positive impacts on female economic empowerment (Adepetu et al., 2005). 


\section{Objectives}

The broad objective of this study is to examine the effect of dry season tomato farming on poverty reduction among women farmers in Niger State, Nigeria.

The specific objectives are to:

(i) identify the socio-economic characteristics of the women tomato farmers,

(ii) examine major sources of resources used for tomato farming,

(iii) ascertain the marketing opportunities and channels for tomato as well as income generated from it,

(iv) determine women expenditure performance in terms of their contributions to basic household needs to reduce poverty, and

(v) determine the effect of dry season tomato farming on poverty reduction among women farmers.

\section{Hypotheses}

1. There is no significant relationship between socio - economic characteristics of the women tomato farmers (household size, education and farming experience) and the effect of dry season tomato farming on poverty reduction.

2. There is no correlation between income derived from dry season tomato farming and its effect on poverty alleviation.

3. There is no significant relationship between monthly expenditure performances (in terms of contributions to food, clothing, housing, health care and children's education) and the effect of dry season tomato farming on poverty reduction.

4. There is no significant difference between household size, income generated and the effect of dry season tomato farming on poverty reduction among women farmers.

\section{METHODOLOGY}

The study is titled" effect of dry season tomato farming on poverty reduction among women farmers in Niger State, Nigeria". Three Local Govt. Areas (LGAs), one from each of the 3 geopolitical zones of the State, were purposively selected for the study (Chanchaga, Lavun and Borgu LGAs).

A total of 15 villages were randomly selected from these LGAs based on the concentration of women tomato farmers in each of the selected LGAs to give a total of 233 women tomato farmers as respondents. A validated Interview Schedule which was subjected to reliability test using Split-half technique $(r=0.88)$ was developed to obtain relevant information.

Data collected were analyzed using descriptive (frequency, percentages and means) and inferential statistics (Chi-square, Cobb-Douglas multiple regression model, Pearson correlation and Analysis of Variance (ANOVA) were employed to test the hypotheses.

\section{Measurement of variables}

1. The effect of dry season tomato farming on poverty reduction was measured on 4-point Likert rating scale and values were assigned accordingly (very effective $=4$ points, effective=3points, ineffective=2points and very ineffective=1point). 
Journal of Agricultural Extension

Vol. 13 (2) December 2009

2. Contributions of women tomato farmers to some basic household expenditures(that is, food, housing, clothing, health care and children's education) were measured on 5 point Likert rating scale as very high $=5$ points, high=4points, average $=3$ points, ineffective $=2$ points and very ineffective $=1$ point ).

3. The socio-economic characteristics (education, household size and tomato farming experience) were categorized and measured at ordinal level of measurement

4. Explicit form of Cobb-Douglas function form of the Regression equation is written as;

5. $\ln Y=b o+b 1 \ln X 1+b 2 \ln X 2+b 3 \ln X 3+b 4 \ln X 4+b 5 \ln X 5+U$,

6. where $\mathrm{In}=$ natural logarithm, bo= constant, $\mathrm{U}=$ error term , $\mathrm{Y}($ dependent variable $)=$ Effect of dry season tomato farming on poverty reduction, $X 1=$ Contribution to food, $\mathrm{X} 2=$ housing, $\mathrm{X} 3=$ clothing, $\mathrm{X} 4=$ health care and $\mathrm{X} 5=$ children's education.

\section{RESULTS AND DISCUSSION}

\section{Demographic and socio - economic characteristics of women tomato farmers}

Findings in Table1revealed that over one-half of the women farmers $(52.3 \%)$ had formal education, married (53.2\%) and most of them had household size ranging from 4 to 9 people $(78.4 \%)$. Though less than one-half of them practiced farming as their major occupation but over one-third had between quarter of an hectare and one hectare of tomato farms, while majority had more than two years farming experience. According to Becker (1991), family size is an important determinant of whether a family or individuals in poverty because the official measure incorporates family size. More so, theory of demand for children revealed that the number of children in a family will depend on the family income and costs of children. Therefore, income plays a role in family size because farmers with higher income are more able to afford additional children. In terms of the cost of children, costs associated with having children include food, clothing and health care expenses among others. However, large household size may help in the provision of family labour on the tomato farms. 
TABLE1: Demographic and socio-economic characteristics of women tomato farmers

\begin{tabular}{|c|c|c|}
\hline Variables & Frequency & Percentage \\
\hline \multicolumn{3}{|c|}{ Highest educational level attained } \\
\hline Post secondary school & 5 & 2.1 \\
\hline Secondary & 42 & 18.0 \\
\hline Primary & 75 & 32.2 \\
\hline Koranic & 38 & 16.3 \\
\hline No formal education & 73 & 31.3 \\
\hline Total & 233 & 100.0 \\
\hline \multicolumn{3}{|l|}{ Marital status } \\
\hline Married & 124 & 53.3 \\
\hline Divorced & 35 & 15.1 \\
\hline Widow & 22 & 9.4 \\
\hline Single & 52 & 22.3 \\
\hline Total & 233 & 100.0 \\
\hline \multicolumn{3}{|l|}{ Religion } \\
\hline Christianity & 117 & 50.2 \\
\hline Islam & 114 & 48.9 \\
\hline Traditional & 2 & 0.9 \\
\hline Total & 233 & 100.0 \\
\hline \multicolumn{3}{|l|}{ Household size } \\
\hline Less than 4 & 22 & 9.4 \\
\hline $4-6$ & 68 & 29.9 \\
\hline $7-9$ & 113 & 48.5 \\
\hline Above 9 & 30 & 12.9 \\
\hline Total & 233 & 100.0 \\
\hline \multicolumn{3}{|l|}{ Major occupation } \\
\hline Farming & 97 & 41.6 \\
\hline Trading & 87 & 37.3 \\
\hline Civil servant & 27 & 11.6 \\
\hline Others & 22 & 9.4 \\
\hline Total & 233 & 100.0 \\
\hline \multicolumn{3}{|l|}{ Size of tomato farm ( ha) } \\
\hline Less than 0.25 & 7 & 3.0 \\
\hline Between 0.25 and 0.49 & 87 & 37.3 \\
\hline Between 0.50 and 0.74 & 27 & 11.6 \\
\hline Between 0.75 and 1 & 107 & 45.9 \\
\hline Above 1 & 5 & 2.1 \\
\hline Total & 233 & 100.0 \\
\hline \multicolumn{3}{|c|}{ Experience in dry season tomato farming } \\
\hline Less than 2 years & 11 & 4.7 \\
\hline Between 2 and 4 years & 24 & 10.3 \\
\hline Between 4.1 and 6 years & 76 & 32.6 \\
\hline Above 6 years & 122 & 52.4 \\
\hline Total & 233 & 100.0 \\
\hline
\end{tabular}

Source: field survey 
Journal of Agricultural Extension

Vol. 13 (2) December 2009

\section{Major source of resources used in dry season tomato farming}

Table 2 showed that the women farmers had access to the use of farm land which was acquired through various sources. Also family friends and personal efforts played a major role in labour supply and finance in the production of tomatoes during the dry season. To buttress the important of credit facilities, Olaleye, (2008) reported a significant difference for both production and income levels of farmers with and without credit facilities. Finding also revealed that the State Agricultural Development Project (NSADP) has continued to play a leading role in the technical information support services to the women farmers, especially in the areas of improved seed varieties which were mostly required by over one-half of the women farmers among others.

TABLE 2: Major sources of resources used for tomato farming

\begin{tabular}{lcc}
\hline Variable & Frequency & Percentage \\
\hline & & \\
Land & 10 & 4.3 \\
Inherited & 55 & 23.6 \\
Leased for farming & 153 & 65.7 \\
Gift from husband/relations & 15 & 6.4 \\
Purchased & 233 & 100.0 \\
Total & & \\
Labour source & 107 & 45.9 \\
Hired & 121 & 51.9 \\
Family / personal & 5 & 2.1 \\
Labour saving devices & 233 & 100.0 \\
Total & & \\
Finance & 73 & 31.3 \\
Personal savings & 117 & 50.2 \\
Gift from husband/friends/relations & 43 & 18.5 \\
Borrowed & 233 & 100.0 \\
Total & & \\
Major source of technical information & 135 & 57.9 \\
Niger State Agric.Dev.Project & 10 & 4.3 \\
Fadama Project & 88 & 37.8 \\
Friends and relations & 233 & 100.0 \\
Total & & \\
Types of technical information & 116 & 18.4 \\
Improved seed varieties & 50 & 100.0 \\
Fertilizer application / manuring & 3 & 21.5 \\
Planting period / spacing & 43 & \\
Pest and disease control & 21 & \\
Storage and packaging technologies & 233 & \\
Total & & \\
\hline Source: field survey & & \\
\hline
\end{tabular}

Source: field survey 


\section{Marketing and marketing channels for tomatoes}

This section discusses findings on the various marketing outlets for tomato, frequency at which this was being done, methods of selling and the average monthly income generated from sales of tomatoes by women farmers. Therefore, findings in Table 3 showed that majority of the women farmers sold their produce at village markets $(61.4 \%)$ compared with sales at farm gates $(31.3 \%)$ and urban markets $(7.3 \%)$. The choice of village markets by majority of them might be connected with high cost of transportation and bad roads. In view of this, the women farmers might experience lower monetary returns due to the activities of middlemen which is a common phenomenon in most rural or village markets. The frequency at which the women disposed their produce either in bulks or retailing could enhance their abilities to purchase other goods and services thereby reducing the incidence of poverty. Moreover, availability of appropriate storage facilities and processing technologies could discourage the sales of tomatoes at give away prices at the peak of harvest.

TABLE 3: Tomato marketing and marketing channels

\begin{tabular}{lcc}
\hline Variable & Frequency & Percentage \\
\hline Selling points & & \\
Farm gate & 53 & 22.7 \\
Village markets & 143 & 61.4 \\
Urban markets & 37 & 15.9 \\
Total & 233 & 100.0 \\
Frequency of tomatoes marketing & & \\
Daily & 53 & 22.7 \\
Weekly & 107 & 45.9 \\
Fortnightly & 73 & 31.3 \\
Total & 233 & 100.0 \\
Method of sales & & \\
Retailing only & 89 & 38.2 \\
Bulk sales only & 33 & 14.2 \\
Both retailing and bulk sales & 111 & 47.6 \\
Total & 233 & 100.0 \\
Average monthly sales of tomatoes ( Naira ) & & \\
N1,000 - N5,000 & 72 & 30.9 \\
N6,000 - N10,000 & 121 & 51.9 \\
N10,000 - N15,000 & 28 & 12.0 \\
Above N15,000 & 12 & 5.2 \\
Total & 233 & 100.0 \\
\hline
\end{tabular}

Source: field survey 
Journal of Agricultural Extension

Vol. 13 (2) December 2009

\section{Expenditure performance in terms of contributions to family basic needs}

This section considered levels of women contributions to food, clothing, housing, health care and children's education based on their earnings from tomato farming. Therefore, Table 4 revealed that contributions to clothing was average $(37 \%)$, high for food $(35 \%)$, very high for housing (36\%) and low for both health care (37.3\%) and children's education (47.2\%). The findings suggested that food, clothing and housing were given greater attention in their expenditures with a view to reducing poverty, while health care and children's education received little consideration. However, reasonable poverty alleviation strategies should encompass adequate provisions for good health care and education of children with a view to eradicating poverty in the societies not only for now but also for generations to come. Generally, majority of the women indicated that dry season tomato farming had positive effect(very effective/effective) on poverty reduction among them(Table 5).It implies that most women $(70.4 \%)$ were more disposed to dry season tomato farming to meet their basic needs.

TABLE 4: Contributions to household expenditures based on income generated from sales of tomatoes by women the farmers

\begin{tabular}{lccccc}
\hline $\begin{array}{l}\text { Expenditure I } \\
\text { performance }\end{array}$ & Very high & High & Average & Low & Very low \\
\hline Food & $40(17.2 \%)$ & $81(34.8 \%)$ & $81(34.8 \%)$ & $17(7.3 \%)$ & $14(6.0 \%)$ \\
Clothing & $65(27.9 \%)$ & $47(20.2 \%)$ & $86(36.9 \%)$ & $14(6.0 \%)$ & $21(9.0 \%)$ \\
Housing & $77(33.0 \%)$ & $56(24.0 \%)$ & $62(26.6 \%)$ & $31(13.3 \%)$ & $7(3.0 \%)$ \\
Health care & $56(24.0 \%)$ & $16(6.9 \%)$ & - & $87(37.3 \%)$ & $74(31.8 \%)$ \\
Children's & & & & & \\
education & $26(11.2 \%)$ & $19(8.2 \%)$ & $34(14.6 \%)$ & $110(47.2 \%)$ & $44(18.9 \%)$ \\
\hline
\end{tabular}

Source: field survey

TABLE 5: Effect of dry season tomato farming on poverty reduction as indicated by the women farmers

\begin{tabular}{lcc}
\hline Effect of dry season tomato farming & Frequency & Percentage \\
\hline Very effective & 69 & 29.6 \\
Effective & 95 & 40.8 \\
Ineffective & 22 & 9.4 \\
Very ineffective & 47 & 20.2 \\
Total & 233 & 100.0 \\
\hline
\end{tabular}

Source: field survey 


\section{RESULTS OF TESTED HYPOTHESES}

Results of Chi - Square tests in Table 6 showed a significant relationship between each of these variables (i.e. educational level, household size and farming experience) and the effect of tomato farming on poverty reduction. This implies that the higher these variables are the stronger the effect of dry season tomato farming on poverty alleviation. Similarly, Pearson correlation test showed a positive correlation between earnings from tomato farming and its effect on poverty reduction, $(r=0.85, P<0.05)$.Also, Cobb-Douglas regression analysis showed a significant relationship between expenditure performance of women and the effect of dry season tomato farming on poverty alleviation $(\mathrm{F}=6.54, \mathrm{P}<0.05)$.It further revealed that food $(\mathrm{t}=$ $2.32, \mathrm{P}<0.05)$, clothing( $\mathrm{t}=-3.56, \mathrm{P}<0.05)$ and housing $(\mathrm{t}=-3.85, \mathrm{P}<0.05)$ were significant in explaining 62 percent variation in the effect of dry season tomato farming on poverty reduction .Analysis of variance (ANOVA) also showed a significant difference between household size, income generated and the effect of dry season tomato farming on poverty reduction $(F=172.53, P<0.05)$. This suggests that household size and income generated from tomato farming can make a significant difference in the effect of dry season tomato farming on poverty alleviation.

\section{TABLE 6: Regression Analysis}

$$
\begin{aligned}
& \text { Multiple } \mathrm{R}=0.65 \\
& \mathrm{R}^{2}=0.62 \\
& \text { Adjusted } \mathrm{R}^{2}= \\
& 0.60
\end{aligned}
$$

ANOVA

\begin{tabular}{lccccc}
\hline & $\begin{array}{c}\text { Sum of } \\
\text { square }\end{array}$ & df & F-value & P-value & Decision \\
\hline Regression & 7.446 & 51.489 & & & \\
$\begin{array}{l}\text { Residual } \\
\text { Total }\end{array}$ & 50.593 & 222.23 & 6.536 & $\mathrm{P}<0.05$ & Sig. \\
& 58.039 & 227 & & & \\
& $\begin{array}{c}\text { Beta } \\
\text { coefficient }\end{array}$ & t-value & P-value & Decision & \\
\hline Food $\left(\log \mathrm{X}_{1}\right)$ & -.148 & -2.32 & .02 & $\mathrm{~S}$ & \\
Clothing $\left(\log \mathrm{X}_{2}\right)$ & -.229 & -3.56 & .00 & $\mathrm{~S}$ & \\
Housing $\left(\log \mathrm{X}_{3}\right)$ & -.242 & -3.85 & .00 & $\mathrm{~S}$ & \\
Health & .029 & .457 & .65 & $\mathrm{NS}$ & \\
care $\left(\log \mathrm{X}_{4}\right)$ & .107 & 1.690 & .09 & $\mathrm{NS}$ & \\
Children's & & & & & \\
educ. $\left(\log \mathrm{X}_{5}\right)$ & & & & & \\
\hline
\end{tabular}

$S=$ Significant, $N S=$ Not significant

Dep.Var (log Y): Effect of dry season tomato farming on poverty reduction. 
Journal of Agricultural Extension

Vol. 13 (2) December 2009

TABLE 7: Analysis of Variance (ANOVA)

\begin{tabular}{lcccccc}
\hline & $\begin{array}{c}\text { Sum of } \\
\text { square }\end{array}$ & df & $\begin{array}{c}\text { Mean } \\
\text { square }\end{array}$ & F & P-value & Decision \\
Regression & 161.722 & 2 & 80.861 & 172.525 & .000 & Significant \\
Residual & 107.797 & 230 & .469 & & & \\
Total & 269.519 & 232 & & & & \\
\hline
\end{tabular}

TABLE 8: Chi - Square results

\begin{tabular}{lcccc}
\hline Variables & $\mathbf{X}^{2}$ Value & df & P value & Decision \\
\hline Household size & 246.29 & 9 & $\mathrm{P}<0.05$ & Significant \\
Highest educational level & 353.33 & 12 & $\mathrm{P}<0.05$ & Significant \\
Tomato farming experience & 181.73 & 9 & $\mathrm{P}<0.05$ & Significant \\
\hline
\end{tabular}

\section{CONCLUSION}

It can be concluded that dry season tomato farming had, to some extent, enhanced the capabilities of women tomato farmers in their contributions to household basic needs with a viewing to reducing the effect of poverty. It is therefore recommended that women in the rural areas should be encouraged to contribute more to the educational and health needs of their families with a view to eradicating poverty. Government should also complement the efforts of the women farmers by embarking on programmes that will further empower the women economically. 


\section{Journal of Agricultural Extension \\ Vol. 13 (2) December 2009}

\section{REFERENCES}

Adepetu,A.A., Olaniyan,J.A. and Daloeng,I.O.(2005):Institution interactions vegetable marketing in Jos. A case study of Farin Gada tomato market.pp3 - 15.

Becker,G.(1991): A treatise on the family change 5 (Cambridge and London), Havard University Press.

European Commission (1996): Commissioned paper on relations between EU and ACP countries on the events of $21^{\text {st }}$ Century, Brussels, European Commission.

Kelly,D. Dawel,L. and Suraiya,B.(2003): An integrated economic and social analysis to assess the impact of vegetable and fishpond technologies on poverty in rural Bangladesh: EPTD Discussion Paper No 102/FCND Discussion Paper163, p114.

Olaleye,R.S.(2008): "Effect of agricultural credit on the development of small scale farming in Lavun LGA of Niger State, Nigeria" Journal of Management Enterprise Dev. Vol.5,No. 2,pp. $80-82$.

United Nations (1997): Bulletin on eradication of poverty, 3 New York.

World Bank (1996): Poverty reduction and the World Bank progress and challenges in the 1990s, Washington, D.C.p4. 